Journal of

Strategic Management

(JSM)

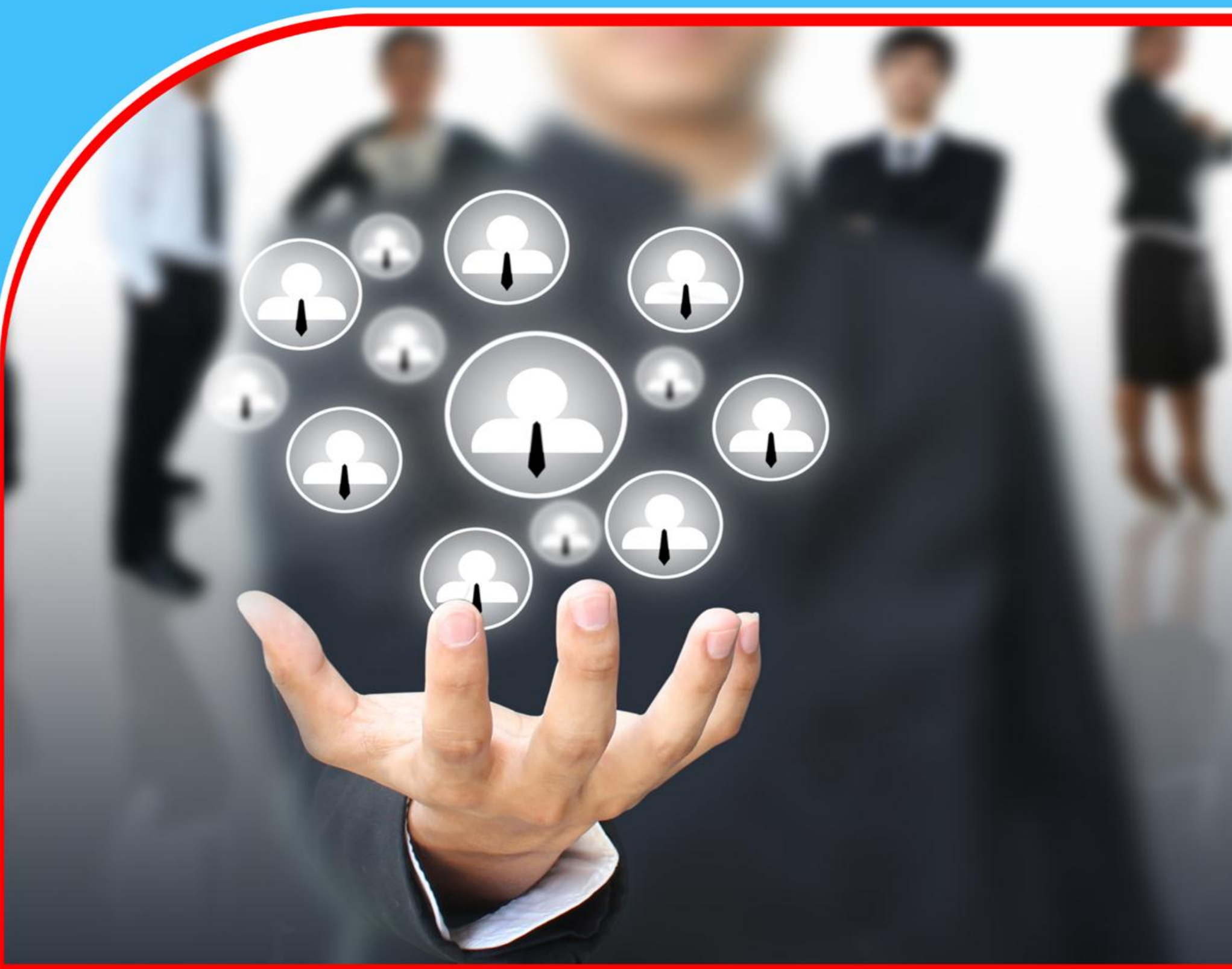

International Procurement and Supply Network Management in the Post COVID 19 Era in Nigeria: A Literature Review

Dr. Akintokunbo Oluwarotimi Odunayo and Arimie Biebele Emmanuel

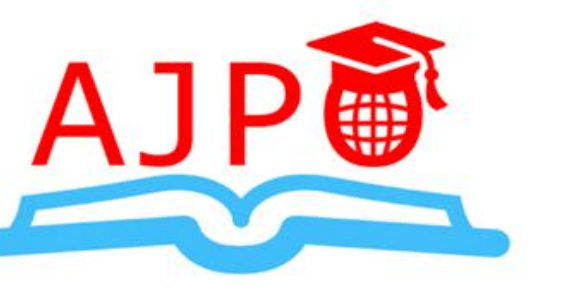




\title{
International Procurement and Supply Network Management in the Post COVID 19 Era in Nigeria: A Literature Review
}

\author{
Dr. Akintokunbo, Oluwarotimi Odunayo
}

Department of Management, Faculty of Management Sciences, Rivers State University, NkpoluOroworukwo, Port Harcourt, Nigeria.

\section{Arimie, Biebele Emmanuel}

Department of Marketing (Supply Chain and Logistics Option), Faculty of Management Sciences, Rivers State University, Nkpolu-Oroworukwo, Port Harcourt, Nigeria.

\begin{abstract}
Introduction: The global economy has been greatly affected by the outbreak of the COVID-19 pandemic and its impact on the oil and gas industry is also being felt immensely as the industry relies heavily on the importation of the goods and services that they require to run their operations effectively and efficiently and the only way to get to the final destination of these company is through a well-managed supply network.

Purpose: The purpose of this study was to examine international procurement and supply network management in the post COVID 19 Era in Nigeria. Being a literature review, the paper adopted a desk research methodology.

Findings: The findings of the review of literature reveal that international procurement significantly influence and predicts supply network management performance. It also shows that COVID-19 has negatively affected both international procurement and supply network management, and that the phrase supply network management, instead of supply chain management, is most appropriate to describe the activities and relationships between and amongst individuals, enterprises, facilities and information, materials and services systems that connects supplier's suppliers to customer's customers capturing the multiple and complex relationships that exists amongst them.
\end{abstract}

Keywords: International Procurement, Supply Chain Management, Supply Network Management, COVID-19. 
Journal of Strategic Management

ISSN 2520-0461 (Online)

Vol.6, Issue 1, pp 17 - 25, 2021

\section{INTRODUCTION}

The primary duty of every procurement system is to effectively and efficiently acquire inputs for production/operations/processing and delivery of the semi-finished or finished goods and works to the final consumers through an agile, reliable and profitable supply network management system. However, every organization has one constraint or the other in their supply network management system which aims to maximize profit by converting all the operational factors/resources that are limiting the process and making them more efficient. The emergence of the COVID-19 pandemic as an additional constraint to global business has seriously disrupted international procurement practices, with negative consequences on the global supply network.

COVID-19 has drastically reduced international procurement in particular and global trade in general as a lot of companies are beginning to source for their inputs for production and operations internally/locally, and the Nigerian oil and gas industry is not an exception. The operations of the oil and gas industry in Nigeria, like any other in the world is highly technical and so a lot of the equipment, spares and consumable are procured from different parts of the world for effective and efficient production/processing. The financial implications of COVID-19 on international procurement and supply networks are highly significant. Majority of the oil and gas internationally procured equipment, tools, spares and other materials are delivered to Nigeria by sea freight because of the lower cost of sea freight over air freight. COVID-19 was first reported in Wuhan, China in December, 2019 and according to the Institute of Shipping Economics and Logistics (ISL), a body that monitors over $60 \%$ of the sea ports globally, the global container throughput index, which measures the number of people and goods that pass-through shipping ports daily, stood at 134 points by their rating. However, because of the impact of COVID-19, it went from 134 points down to 115.4 in January 2020, meaning it went down by $13.9 \%$, but later went up to 119 points by December 2020, which translates into a 3.0\% improvement. The container throughput which shows the degree of international procurement and supply network went up from 119 in December 2020, to 120.8 points in January 2021. By the last publication of ISL as at June 2021, it has gone up slightly to 126.4, which translates into a $4.4 \%$ increase/improvement.

Ford, Gadde, Hakansson and Snehota (2003), opines that a supply network is not only a network of individuals but a result of complex interactions within and between companies in relationships over time. A supply chain includes all activities, functions and facilities (directly or indirectly) in the flow and transformation of goods and services from the material stage to the end user (Sherer, 2005). It is a network of organizations which starts from suppliers to the destination of the final consumers, while integrating the demand side and the supply side seamlessly through strategic coordination of all the associated resources and activities.

This paper examines the relationship between international procurement and supply network management. Though there are many measures of supply network management performance, including market share, customer satisfaction, customer experience, service quality, etc, the performance measures of supply network management used in this paper are: (1) Agility, (2) Delivery reliability, and (3) Profitability 


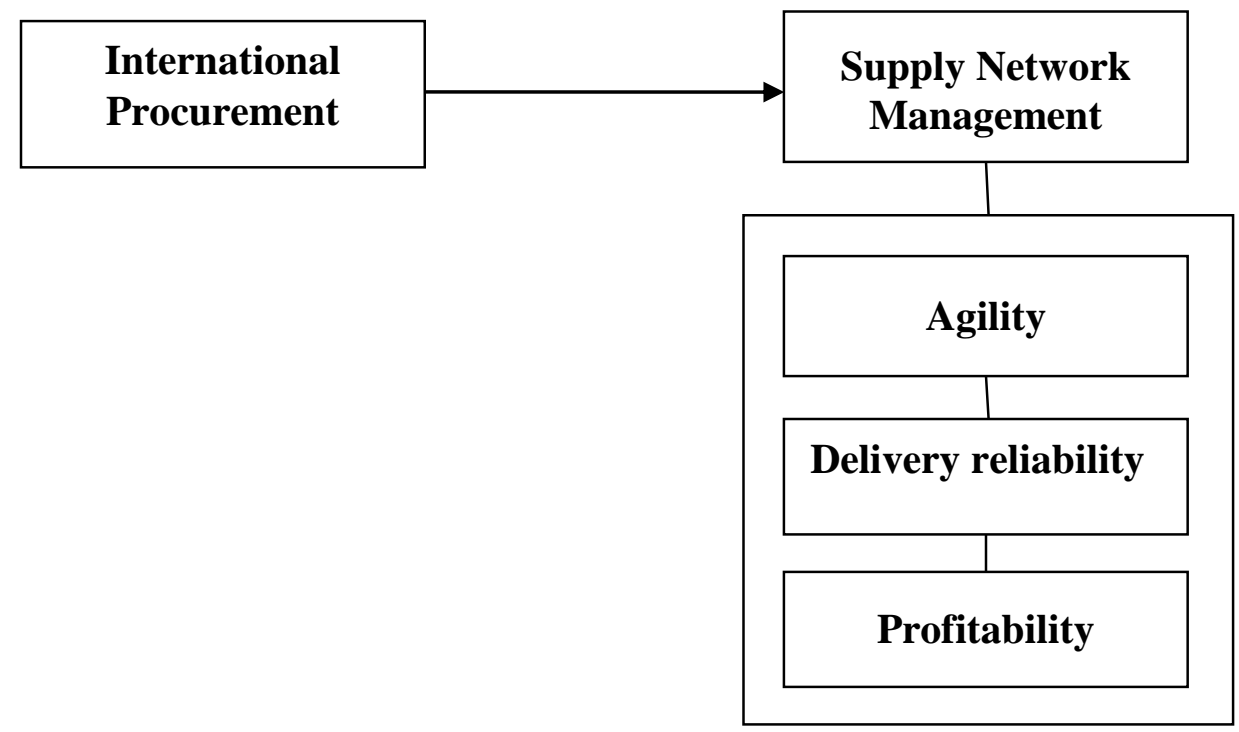

Fig. 1: Conceptual Framework of the link between International Procurement and Supply Network Management.

Source: Researcher's Conceptualization from review of literature (2021)

\section{LITERATURE REVIEW}

\section{The concept of International Procurement}

International procurement which is mostly referred to by many authors as international purchasing is a strategic element of competitive advantage in global supply network management system as the world is now a global village. Wanzala, (n.d), states that, international procurement relates to a commercial purchase transaction between a buyer and a supplier located in a different country. According to the dictionary of international trade (2017), international procurement is the process of allowing firms around the world to bid on contracts for goods and services. For us, we prefer to define international procurement as the process of sourcing and acquiring needed goods and services from sources that are outside a defined geographical location called a Country, Nation or state that has its own sovereignty/political independence. International procurement is generally referred to as importation, buying from abroad, international sourcing or foreign procurement.

International procurement processes, activities and documentations are far more complex than domestic/local procurement in the sense that there are many challenges to face in the process, like language, cultural, foreign exchange, legal differences, etc that are associated with it. While the general business reason for international procurement is to gain competitive advantage which includes access to lower prices and higher quality of goods and service, better delivery performance, improving customer service/experience and having access to ever changing technology and other innovations) over other competitors, some other specific reasons for international procurement of goods and services are: lack of availability locally, being available locally but the specific features or quantities preferred/required by the buyer may only be available, etc. International procurement has the same general objectives of procurement which are to procure the right goods and services at 
Journal of Strategic Management

ISSN 2520-0461 (Online)

Vol.6, Issue 1, pp 17 - 25, 2021

the right time, from the right source, at the right price/total cost, to be delivered at the right place, in the right quantity and quality.

\section{The Concept of Supply Network Management}

Lee and Billington (1992), described a supply chain as a network of manufacturing and distribution sites that procure raw materials, transform them into intermediate and finished products, and distribute the finished products to customers. In the opinion of Frazelle (2002), a supply chain is a network of enterprises, individuals, facilities and information/material handling systems that connects supplier's supplier to customer's customer. Christopher (1998), states that a supply chain is a network of organizations that are involved, through upstream and downstream linkages, in the different processes and activities that produce value in the form of products and services in the hands of the ultimate customer. For Aitken et al. (2005), a supply chain is the network of connected and interdependent organizations that work together to enable the flow of products into markets. For Nagurney (2006), Supply chains are the critical infrastructure for the production, distribution, and consumption of goods as well as services in our globalized Network Economy.

The Chartered Institute of Procurement and Supply, CIPS, (n.d) stated that a supply network is developed by connecting multiple supply chains, while the operational activities within an organisation are classified as a supply Chain, and that the intent of a supply chain is to deliver value to its organisation. The CIPS (n.d) further stated that the integration of a company's suppliers and consumers supply chain and its interconnections with its own internal organisation's supply chain activity create a Supply network. The supply network view allows an organisation to have a holistic view of all aspects and their impacts on the focal organisation's supply chain. Therefore, a supply network is a combination of multiple supply chains that network in a business environment and cross-linked structures locally and internationally.

A network of companies to which interdependent organizations have linked up can be regarded as a supply network. Organizations co-operate in order to control, manage and improve material and information flows from suppliers to end users. A supply chain is described as a chain that creates products or services and forwards them from suppliers to customers. However, a supply network would be a more appropriate term to describe a supply chain. The network consists of company's partners as well as various suppliers and clients. Also, customers of the customers are part of the network that a company builds around it (Christopher, 1998). Kakwezi (2015), suggests that networks relate more to complex structures while chains relate simply to sequential set of nodes and links. Harland, Lamming, Zheng and Johnsen (2001), described a network as a more complex structure, where organizations can be interlinked and with two-way exchange between and amongst them.

\section{Agility}

Preiss (2005) defined agility as a comprehensive response to the business challenges of profiting from rapidly changing, continually fragmenting, global markets for high quality, high-performance, and customer-configured goods and services. It is dynamic, context-specific, aggressively changeembracing, and growth oriented. Agility is a comprehensive response to new competitive forces that have undermined the dominance of a mass production system. It maximizes profits by providing 
Journal of Strategic Management

ISSN 2520-0461 (Online)

Vol.6, Issue 1, pp 17 - 25, 2021

exactly what the customer requires. However, owing to the broadness of Preiss's definition it is hard to accept agility as so broad a concept. Goldman, Naegel and Preiss (1995), the definition is notably simpler (Goldman et al, 1995): Agility is the ability of an enterprise to quickly respond to changes in an uncertain and changing environment.

Harrison, Christopher and Van-Hoek (1999), stated that the concept of agile supply chains was introduced to transfer and apply the winning strategy of agility to that of supply chains as a newly accepted unit of business. Agility in the context of supply chain management focuses on "responsiveness" (Lee and Lau, 1999; Christopher and Towill, 2000). In the view of KisperskaMoron and Swiercze (2008), for a supply chain to be truly agile, it must have some distinguishing attributes which includes process integration and networking.

According to Planergy (n.d.), supply chain agility refers to an organization's ability to smoothly respond to market changes. These changes are vast and knotted, involving everything from changes in customer preferences, to economic and market volatility, and competitor disruption, amongst others. Data shows that companies that practice supply chain agility have higher customer service rankings than their competition. Christopher (2000), stated that agility is a business-wide capability that embraces organizational structures, information systems, logistics processes, and, in particular, mindsets. From his perspective, a key characteristic of an agile organization is flexibility. Agility might, therefore, be defined as the ability of an organization to respond rapidly to changes in demand, both in terms of volume and variety. Aitken, Childerhouse, Christopher and Towill (2005) defined agility as a business-wide capability that embraces organizational structures, information systems, logistics processes and mindsets. Agility is considered to be a new trend that has its roots in the early 1990's, with a background on time based competition and other philosophies. In literature generally, agility is considered to be synonymous with flexibility. Planergy (n.d), further asserted that successful supply chain agility relies on the understanding that external factors shape your supply chain logistics regardless of how steady things are at this moment; exploring value chain components that are most affected by industry disruption; integrating more proactive technology and process to address pain points in the value chain; ongoing monitoring and analysis of new processes, production cost savings, and cross-functional collaboration and continuing to adjust processes when needed.

\section{Delivery Reliability}

Delivery reliability has to do with the capability of providing goods and services to customer, it encompasses delivering the right material(s) or services at right time, in the right quantity and quality, at the right place and with right documentation. Fundamentally, delivery reliability by firms and supply networks is dependent on information for two key reasons namely; information as an input for formulation of delivery process strategies and, information as a control measure for achieving high levels of delivery times (Fawcett, Calantone \& Smith 1997; Hicks, Culley \& McMahon 2006). Furthermore, stimulated by the consciousness of the impacts of information for companies and supply chains, researchers have argued that integrated information flow is needed to overcome problems linked with fractured supply networks made up of geographically dispersed partners from different industries and to align demand and supply (Patnayakuni, Rai, \& Seth (2006).

Delivery reliability poses production planning challenges in terms of how delivery will be achieved by suppliers alongside a quoted delivery date and how anticipations of customers are shaped through 
Journal of Strategic Management

ISSN 2520-0461 (Online)

Vol.6, Issue 1, pp 17 - 25, 2021

integrated information flow with supply chain partners. Sillanpää (2011) asserted that delivery reliability of the orders is measured with the help of the operation control system. Sales enter the delivery date into the system. The shipment is also recorded into the system. In delivery reliability, the dates of promised time of delivery from sales and the dispatched order are compared. The delivery is in time if the dates match. The production must not be completed too early since in this case storing will cause problems and capital is unnecessarily bound to the production process. Furthermore, customers would like to avoid receiving the products too early because prefabricated products are often taken directly to the customers' production process. Hence delivering goods beforehand raises a need for warehousing and increases the amount of customers' capital bound to production.

\section{Profitability}

According to Upton (1961), profitability is the ability of a given investment to earn a return from its use. For Hermanson (1989), profitability is an organizations' ability to generate income, and its inability to generate income is a loss. He further asserts that if the income generated is greater than the input cost, it will simply be referred to as profitability. But if the income is less than the input cost, it can lead to poor performance and amount to a loss. Therefore, it can be concluded that every business should earn sufficient profits in order to survive and grow over a long period.

Profit is the difference between the total revenue and total cost, including direct and indirect cost of production and taxes. It is the net amount after all deductions has been made within a given period. Profit-maximizing firms select both the capacities associated with the various supply chain network activities as well as the product quantities. Maximization of profit is a very crucial objective for a firm to remain in business and to withstand competition from firms operating in similar industry. It is a major pre-requisite for long-term survival and success of a firm while it is a key pre-condition for the achievement of other financial goals of a business entity (Gitman \& Zutter, 2012). Profitability is a core measure of the performance of a firm. In traditional economic model of a firm, it is assumed that a firm's objective is to maximize short-run profits, that is, profits in the current period which is generally taken to be a year. Based on the above, the firm's objective is to continue to make profit year in year out as a going concern.

\section{CONCLUSION AND RECOMMENDATION}

The findings of this review of literature reveal that international procurement significantly influences and predicts supply network management performance. The review further shows that COVID-19 has negatively affected both international procurement and supply network management, and that the phrase supply network management, instead of supply chain management, is most appropriate to describe the activities and relationships between and amongst individuals, organisations, facilities and information, materials and services systems that connects supplier's suppliers to customer's customers capturing the multiple and complex relationships that exists amongst them. It is hereby recommended that companies in the oil and gas industry in Nigeria should in preparation for post COVID-19, develop the capacity of their staff in the area of agility and delivery reliability so as to increase and maximize their profitability potentials. 
Journal of Strategic Management

ISSN 2520-0461 (Online)

Vol.6, Issue 1, pp 17 - 25, 2021

www.ajpojournals.org

\section{REFERENCES}

Aitken, J., Childerhouse, P., Christopher, M., \& Towill, D. (2005). Designing and managing multiple pipelines. Journal of Business Logistics 26(2), 73.

Bruce, M., Daly, L., \& Towers, N. (2004). Lean or agile: A solution for supply chain management in the textiles and clothing industry? International Journal of Operations \& Production Management, 24(2), 151-170.

Chartered Institute of Procurement and Supply Management, UK (n.d). Supply network design. Retrieved from: https://www.cips.org/knowledge/procurement-topics-and-skills/supplychain-management/supply-network-design/. Accessed on the $25^{\text {th }}$ of August, 2021.

Christopher, M. (1998). Logistics and supply chain management: Strategies for reducing cost and improving service (2th ed.). London: Financial Times Management

Christopher, M. (2000). The agile supply: Competing in volatile markets. Industrial Marketing Management, 29, 37-44.

Christopher, M., \& Peck, H. (2004). Building the resilient supply chain. The International Journal of Logistics Management, 15(2), 1-13.

Christopher, M. \& Towill, D. R., (2000). Supply chain migration from lean and functional to agile and customized. International Journal on Supply Chain Management, 5(4), 206-213.

Dictionary of International Trade (2017). International procurement. Retrieved from: https://www.globalnegotiator.com/en/dictionary-of-international-trade/. Accessed on the $25^{\text {th }}$ of August, 2021.

Fawcett, S. E., Calantone, R., \& Smith, S. R. (1997). Delivery capability and firm performance in international operations. International Journal of Production Economics, 51(3), 191-204.

Frazelle, E., H. (2002). Supply chain strategy: The logistics of supply chain management. McGraw Hill, New York.

Ford, D., Gadde, L. E., Hakansson, H., \& Snehota, I. (2003). Managing business relationships. $2^{\text {nd }}$ edition. John Wiley, p.18.

Gitman, L. J., \& Zutter, C. J. (2012). Principles of managerial finance. Boston: Prentice hall.

Goldman, S., Naegel, R. \& Preiss, K. (1995). Agile competitors and visual organisations: Strategies for enriching the customer.

Harland, C. M., Lamming. R. C., Zheng, J. \& Johnsen, T. E. (2001). Taxonomy of supply networks. Journal of supply chain management, 37(4), 21-27.

Harrison, A., Christopher, M., \& Van-Hoek, R. (1999). Creating the agile supply chain. School of Management Working Paper, Cranfield University, Cranfield.

Hermanson (1989). Accounting Principles: A Business Perspective, Financial Accounting (Chapters $1-8)$. A Textbook. Equity Open College Textbook. 
Hewitt, F. (1999). Supply or demand? Chains or pipelines? Co-ordination or control? Proceedings from International Symposium in the Information Age, Florence, p. 785-90, 1999.

Hicks, B., J. Culley, S., J. \& McMahon, C., A. (2006). A study of issues relating to information management across engineering SMEs. International Journal of Information Management, 26(4), 267-289.

Institute of shipping economics and logistics (n.d). ISL container throughput index. Retrieved from https://www.isl.org/ . Accessed on the $25^{\text {th }}$ of August, 2021.

Kakwezi, P. (2015). Re: What is the difference between Supply Network Design (SND) and Supply Chain Network Design (SCND)? Retrieved from: https://www.researchgate.net/post/What_is_the_difference_between_Supply_Network_Des ign_SND_and_Supply_Chain_Network_Design_SCND/55b9b8096225fff14b8b457d/. Accessed on the $25^{\text {th }}$ of August, 2021.

Kisperska-Moron, D., \& Swierczek, A. (2008). The agile capabilities of Polish companies in the supply chain: An empirical study. International Journal on Production Economics.

Lee, H. L., \& Billington, C. (1992). Managing supply chain inventory: Pitfalls and opportunities, Sloan Management Review, 65 - 73.

Lee, W., B. \& Lau, H., C. (1999). Factory on demand: The shaping of an agile network. International Journal of Agile Manufacturing Systems, 1(2), 83-87.

Nagurney A. (2006). Supply Chain Network Economics: Dynamics of Prices, Flows, and Profits, Edward Elgar Publishing. Cheltenham, England.

Patnayakuni, R., Rai, A. \& Seth, N. (2006). Relational antecedents of information flow integration for supply chain coordination. Journal of Management Information Systems, 23(1), 13-49.

Planergy (n.d). Supply chain agility and how to achieve it. Retrieved from: https://planergy.com/blog/supply-chain-agility/. Accessed on the 25 ${ }^{\text {th }}$ of August, 2021.

Preiss, K. (2005). Agility - the origins, the vision and the reality. In Proceedings of the international conference on agility.

Rai, A., Patnayakuni, R., \& Seth, N. (2006). Firm performance impacts of digitally enabled supply chain integration capabilities. MIS Quarterly: Journal of Management Information Systems, 30(2), 225-246.

Sherer S. (2005). From supply-chain management to value network advocacy: implications for esupply chains. Supply chain management: An international journal, 110:2 (2005), pp.77-83.

Sillanpää, I. (2011). Supply chain performance measurement in the manufacturing industry. A single case study research to develop a supply chain performance measurement framework. Academic Dissertation presented with the assent of the Faculty of Technology of the University of Oulu, Linnanmaa. Retrieved from: https://www.researchgate.net/publication/273280889 supply_chain performance measurement in the manufacturing industry/ 
Snow, C. C., Miles, R. E., \& Coleman, H. J. (1992). Managing $21^{\text {st }}$ century network organizations. Organisational dynamics. Winter 20(3), 5 - 7.

Upton, H. (1961). Introduction to Business Finance. McGraw Hill, New York.

Wanzala, G. P. (n.d). International procurement process, benefits and challenges. Retrieved from: https://www.google.com.ng/amp/s/slideplayer.com/amp/6178343/. Accessed on the $25^{\text {th }}$ of August, 2021. 